\title{
ANALISIS PEMBERIAN INSENTIF TIDAK KENA PAJAK BEA BALIK NAMA KENDARAAN BERMOTOR TERHADAP KBL BERBASIS BATERAI DI DKI JAKARTA
}

\section{Chairinaya Nizliandry ${ }^{1}$}

${ }^{1}$ Fakultas Hukum, Ilmu Hukum, Universitas Indonesia, chairinaya.nizliandry@ui.ac.id

\begin{abstract}
ABSTRAK
Pajak merupakan sumber penerimaan utama negara dalam fungsinya sebagai budgetair dan sebagai alat untuk mengatur di bidang sosial dan perekonomian dalam fungsinya sebagai regurelend, yang berdasarkan lembaga pemungutannya terbagi menjadi pajak pusat dan pajak daerah. Salah satu bentuk pajak daerah tingkat provinsi ialah bea balik nama kendaraan bermotor yang pada 3 Januari 2020 oleh Gubernur DKI Jakarta diberikan insentif tidak kena pajak terhadap penyerahan kepemilikan Kendaraan Bermotor Listrik (KBL) Berbasis Baterai untuk Transportasi Jalan. Dengan menggunakan pendekatan yuridis-normatif melalui teori validitas hukum dapat dipaparkan diketahui bahwa penerbitan Pergub 3/2020 bertentangan dengan UU 28/2009 namun terharmonisasi dengan Perpres 55/2019 yang merupakan tindak lanjut dari ketentuan Pasal 17 ayat (1) Pergub tersebut, serta melalui teori welfare state dipahami bahwa penerbitan suatu peraturan perundang-undangan juga harus mempertimbangkan beban tanggung jawab pemerintah dalam penyediaan kebutuhan rakyatnya, diantaranya dengan memastikan masyarakatnya dapat hidup di lingkungan yang memiliki kualitas udara yang baik. Sehingga dalam hal ini, konsistensi pemerintah dalam melakukan harmonisasi peraturan perundang-undangan sangat dibutuhkan yang juga diikuti dengan peran serta masyarakat setempat dalam mendukung program pemerintah untuk meningkatkan kualitas hidup
\end{abstract}

ARTICLE INFO

\section{Kata Kunci:}

Pajak Daerah; Insentif Tidak Kena Pajak; Bea Balik Nama Kendaraan Bermotor

\section{Cite this paper:}

Nizliandry, C., 2020.

Analisis Pemberian Insentif Tidak Kena Pajak Bea Balik Nama Kendaraan Bermotor Terhadap KBL Berbasis Baterai Di DKI Jakarta. Widya Yuridika: Jurnal Hukum, 3(2).

\section{PENDAHULUAN}

Pajak memiliki peranan yang sangat dominan terhadap penerimaan negara. Hal ini dapat dilihat dari pendapatan negara 2019 yang terbagi menjadi Penerimaan Perpajakan sebesar $1.786,6 \mathrm{~T}$ atau $82.51 \%$, PNBNP sebesar $378,3 \mathrm{~T}$ atau $17.47 \%$, dan Hibah sebesar $0,4 \mathrm{~T}$ atau $0.02 \% .{ }^{1}$ Penerimaan negara berasal dari rakyat melalui pungutan pajak dan/atau dari hasil kekayaan alam yang ada di dalam negara itu (natural resources). Dua sumber itu merupakan sumber yang penting dalam memberikan penghasilan kepada

1 Kementerian Keuangan Republik Indonesia, “APBN 2019” https://www.kemenkeu.go.id/apbn2019, diakses 1 April 2020. 
negara untuk membiayai kepentingan umum dan akhirnya juga mencakup kepentingan pribadi individu. ${ }^{2}$ Selain daripada itu, terdapat pula penerimaan pemerintah pusat lainnya, yaitu dari bea dan cukai serta Penerimaan Negara Bukan Pajak (PNBP). ${ }^{3}$ Pajak memiliki 2 (dua) fungsi yaitu fungsi budgetair dan fungsi regulerend (fungsi mengatur). Fungsi budgetair dari pajak adalah fungsi yang digunakan untuk mengisi kas negara yang merupakan salah satu sumber yang utama bagi penerimaan negara maupun daerah. Sedangkan fungsi regulerend adalah fungsi yang digunakan untuk mengatur di bidang sosial dan perekonomian yang pada umumnya digunakan dalam rangka mencapai tujuan tertentu yang diharapkan oleh negara/pemerintah. ${ }^{4}$

Berdasarkan lembaga pemungutannya, pajak terbagi menjadi Pajak Pusat dan Pajak Daerah. Pajak Pusat sebagian besar dikelola oleh Direktorat Jenderal Pajak yang mana hasil pungutannya kemudian digunakan untuk membiayai belanja negara. Sementara untuk membiayai belanja Pemerintah Daerah, pada tiap-tiap Daerah Otonom diberikan kewenangan untuk memungut Pajak Daerah berdasarkan Undang-Undang Nomor 32 Tahun 2004 tentang Pemerintah Daerah yang mengubah sistem sentralisasi pemerintahan yang terjadi sebelumnya ke arah desentralisasi dengan pemberian otonomi daerah yang nyata, luas, dan bertanggung jawab kepada daerah ${ }^{5}$. Setiap Pemerintah Daerah dapat menetapkan dan memungut beragam jenis pajak daerah sesuai dengan potensi yang dimilikinya. ${ }^{6}$

Berdasarkan Undang-Undang Nomor 29 Tahun 2009 tentang Pajak Daerah dan Retribusi Daerah, selanjutnya disingkat UU 29/2009, jenis-jenis pajak daerah yang boleh dipungut oleh daerah adalah sebagai berikut:

1. Pajak provinsi terdiri atas:
a. Pajak Kendaraan Bermotor;
b. Bea Balik Nama Kendaraan Bermotor;
c. Pajak Bahan Bakar Kendaraan Bermotor;
d. Pajak Air Permukaan; dan
e. Pajak Rokok.

2. Pajak kabupaten/kota terdiri atas:
a. Pajak Hotel;
b. Pajak Restoran;
c. Pajak Hiburan;
d. Pajak Reklame;
e. Pajak Penerangan Jalan;
f. Pajak Mineral Bukan Logam dan Batuan;
g. Pajak Parkir;
h. Pajak Air Tanah;
i. Pajak Sarang Burung Walet;
j. Pajak Bumi dan Bangunan Perdesaan dan Perkotaan; dan
k. Bea Perolehan Hak atas Tanah dan Bangunan.

2 Rochmat Soemitro, "Pengantar Singkat Hukum Pajak", (Makalah Lokakarya Pendidikan dan Pelatihan Keuangan dan Perpajakan/Pendapatan Daerah, Jakarta, 14 Maret 1986), hlm. 2.

3 Tjip Ismail, Potret Pajak Daerah di Indonesia, (Jakarta: Prenamedia Group, 2018), hlm. 25.

Oyok Abuyamin, Perpajakan, (Bandung: Mega Rancage Press, 2015), hlm. 35

HAW Widjaja, Otonomi Daerah dan Daerah Otonom, (Jakarta: RajaGrafindo Persada, 2002), hlm. 14.

6 Achmad Lutfi, "Penyempurnaan Administrasi Pajak Daerah dan Retribusi Daerah: Suatu Upaya dalam Optimalisasi Penerimaan PAD”, Jurnal Ilmu Administrasi dan Organisasi: Bisnis \& Birokrasi, Vol. XIV, No. 1, Januari 2006, hlm. 3. 
Tujuan diundangkannya UU 28/2009, yaitu didasarkan atas beberapa pertimbangan diantara untuk meningkatkan pelayanan kepada masyarakat dan kemandirian daerah, melalui perluasan objek pajak daerah dan retribusi daerah, dan pemberian diskresi dalam penetapan tarif yang dilaksanakan berdasarkan prinsip: demokrasi, pemerataan dan keadilan, peran serta masyarakat dan akuntabilitas dengan memperhatikan potensi daerah. ${ }^{7}$

Berdasarkan Pasal 9 UU 28/2009, penyerahan kepemilikan Kendaraan Bermotor merupakan objek pajak dari pajak Bea Balik Nama Kendaraan Bermotor (BBNKB). Termasuk dalam pengertian Kendaraan Bermotor adalah kendaraan bermotor beroda beserta gandengannya, yang dioperasikan di semua jenis jalan darat kecuali kereta api; Kendaraan Bermotor yang semata-mata digunakan untuk keperluan pertahanan dan keamanan negara; Kendaraan Bermotor yang dimiliki dan/atau dikuasai kedutaan, konsulat, perwakilan negara asing dengan asas timbal balik dan lembaga-lembaga internasional yang memperoleh fasilitas pembebasan pajak dari Pemerintah; dan objek pajak lainnya yang ditetapkan dalam Peraturan Daerah. ${ }^{8}$ Namun pada 3 Januari 2020, Gubernur DKI Jakarta menetapkan pemberian insentif tidak dikenakan pajak BBNKB terhadap penyerahan kepemilikan Kendaraan Bermotor Listrik Berbasis Baterai (KBL Berbasis Baterai) untuk Transportasi Jalan melalui Peraturan Gubernur Daerah Khusus Ibukota Jakarta Nomor 3 Tahun 2020 tentang Insentif Pajak Bea Balik Nama Kendaraan Bermotor atas Kendaraan Bermotor Listrik Berbasis Baterai (Battery Electric Vehicle) untuk Transportasi Jalan, selanjutnya disingkat Pergub 3/2020.

Pemberian insentif tidak kena pajak BBNKB terhadap KBL Berbasis Baterai tersebut dalam implementasinya diperlukan kajian lebih mendalam berdasarkan sudut pandang Undang-Undang Pajak Daerah dan Retribusi Daerah, sebagai payung hukum yang menaungi kebijakan pemungutan pajak dan retribusi daerah. Selain itu diperlukan juga pemahaman mengenai kewenangan Pemerintah Daerah DKI Jakarta dalam memberikan insentif tidak kena pajak tersebut berdasarkan Undang-Undang Pemerintahan Daerah.

Metode yang digunakan dalam penelitian ini adalah pendekatan yuridis normatif. Pendekatan yuridis yaitu suatu pendekatan yang mengacu pada hukum dan peraturan perundang-undangan yang berlaku' ${ }^{9}$, sedangkan pendekatan normatif, adalah pendekatan yang dilakukan dengan cara meneliti bahan pustaka atau data sekunder terhadap asasasas hukum serta studi kasus yang dengan kata lain sering disebut sebagai penelitian hukum kepustakaan ${ }^{10}$. Penelitian dilakukan melalui studi kepustakaan (library research) sebagai data sekunder yang bertujuan menunjukkan jalan pemecahan masalah penelitian. ${ }^{11}$

Dalam suatu penelitian hukum, data sekunder memiliki kekuatan mengikat ke dalam. ${ }^{12}$ Adapun data sekunder tersebut meliputi bahan-bahan hukum yang,

\footnotetext{
7 Rochmat Soemitro, Asas dan Dasar Perpajakan, (Bandung: Eresco, 1991), hlm. 10.

8 Indonesia, Undang-Undang Pajak Daerah dan Retribusi Daerah, UU No. 28 Tahun 2009, LN No. 130 Tahun 2009, TLN No. 5049, Ps. 9 ayat (2) dan (3).

9 Ronny Hanitjo Soemitro, Metodologi Penelitian Hukum dan Jurimetri, (Jakarta: Ghalia Indonesia, 1990), hlm. 20.

10 Soerjono Soekanto dan Sri Mamudji, Penelitian Hukum Normatif: Suatu Tinjauan Singkat, (Jakarta: RajaGrafindo Persada, 2004), hlm. 13.

11 Bambang Sunggono, Metode Penelitian Hukum, (Jakarta: RajaGrafindo Persada, 2007), hlm. 112.

12 Ibid., hlm. 113-114.
} 
dikelompokkan ke dalam 3 (tiga) bagian, yaitu: ${ }^{13}$ 1) bahan hukum primer, yaitu bahanbahan yang berupa peraturan perundang-undangan dan atau produk-produk hukum lainnya yang mengatur tentang hal-hal yang berkaitan dengan judul penelitian ini antara lain Peraturan Gubernur Nomor 3 Tahun 2020 tentang Insentif Pajak Bea Balik Nama Kendaraan Bermotor Atas Kendaraan Bermotor Listrik Berbasis Baterai (Battery Electric Vehicle) Untuk Transportasi Jalan dan peraturan terkait lainnya; 2) bahan hukum sekunder, yaitu bahan-bahan hukum yang menjelaskan bahan hukum primer dan isinya tidak mengikat, berupa penjelasan terhadap bahan-bahan hukum primer, misalnya buku, majalah, makalah, dan artikel yang berkaitan dengan judul penelitian serta pendapat para pakar hukum; 3) bahan hukum tersier, yaitu bahan yang sifatnya sebagai pelengkap dari bahan hukum primer dan bahan hukum sekunder, seperti kamus Bahasa Indonesia dan kamus hukum.

Metode analisis yang digunakan dalam penelitian ini adalah metode kualitatif, yaitu data yang diperoleh akan dipilih dan disusun secara sistematis untuk selanjutnya dianalisis secara kualitatif dengan menggunakan kerangka berpikir secara deduktif dan induktif untuk memperoleh gambaran tentang pokok permasalahan dan menjawab permasalahan.

\section{HASIL DAN PEMBAHASAN}

1. Pengaturan Terkait Pemberian Insentif Tidak Kena Pajak BBNKB Terhadap KBL Berbasis Baterai Berdasarkan Sudut Pandang Undang-Undang Pajak Daerah Dan Retribusi Daerah

Pada bulan Januari 2019, skor rata-rata ISPU yang diambil di lima wilayah DKI Jakarta menunjukkan angka 59,4. Angka tersebut terus meningkat hingga puncaknya di bulan Agustus dengan skor rata-rata 88,9 walaupun di bulan Mei dan Juli sempat mengalami

Gambar 1. Grafik Indeks Standar Pencemar Udara DKI Jakarta

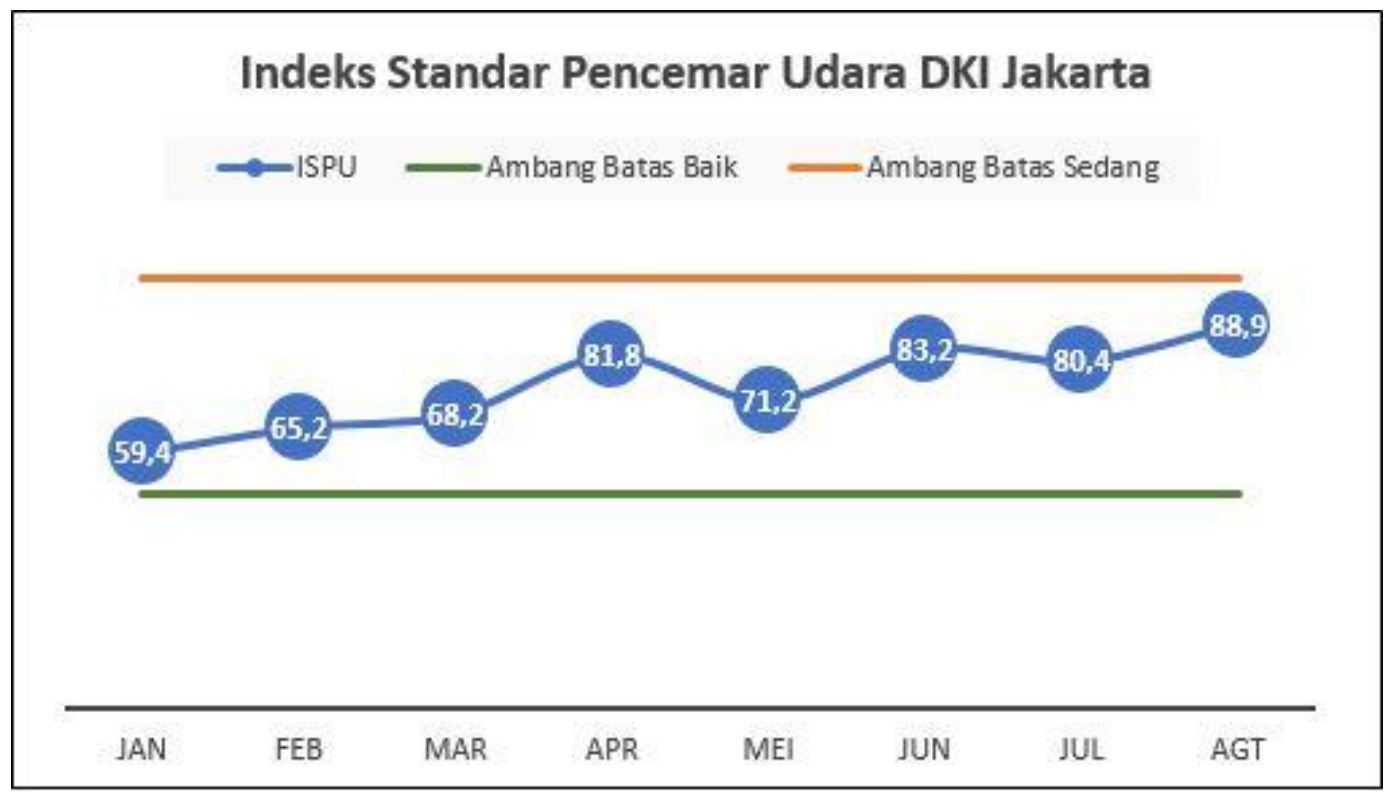

Sumber: http://statistik.jakarta.go.id/kualitas-udara-dki-jakarta-di-2019/

13 Soerjono Soekanto, Pengantar Penelitian Hukum, (Jakarta: UI Press, 1986), hlm. 52. 
penurunan. Walaupun meningkat, kualitas udara di DKI Jakarta sepanjang tahun 2019 sampai dengan bulan Agustus masih tergolong sedang (ISPU 51-100). ${ }^{14}$

Menurut Lampiran Keputusan Menteri Negara Lingkungan Hidup Nomor 45 Tahun 1997 tentang Indeks Standar Pencemar Udara, selanjutnya disingkat Kepmen LH 45/1997, kategori sedang dalam ISPU berarti tangkat kualitas udara yang tidak berpengaruh pada kesehatan manusia ataupun hewan tetapi berpengaruh pada tumbuhan yang sensitif, dari nilai estetika.

Meskipun kualitas udara pada tahun 2019 relatif menurun dari tahun 2018 dimana ISPU per tanggal 16 November 2018 di wilayah DKI2 mencapai angka 234 yang telah masuk ke dalam kategori sangat tidak sehat (ISPU 200-299) ${ }^{15}$, namun pemerintah daerah DKI Jakarta tetap berusaha melakukan tindakan-tindakan pengendalian kualitas udara di DKI Jakarta, salah satunya dengan memberikan insentif pajak BBNKB sebagai tindak lanjut ketentuan Pasal 17 ayat (1) dan ayat (2) Peraturan Presiden Nomor 55 Tahun 2019 tentang Percepatan Program Kendaraan Bermotor Listrik Berbasis Baterai (Battery Electric Vehicle) Untuk Transportasi Jalan, selanjutnya disingkat Perpres 55/2019. Tujuan utama ditetapkanya Perpres 55/2019 ialah untuk meningkatkan efisiensi energi, ketahanan energi, dan konservasi energi sektor transportasi, dan demi terwujudnya energi bersih, kualitas udara bersih dan ramah lingkungan, serta sebagai wujud komitmen Indonesia menurunkan emisi gas rumah kaca, sehingga pemerintah memandang perlu untuk mendorong percepatan program KBL Berbasis Baterai (Battery Electric Vehicle) untuk tranportasi jalan. ${ }^{16}$ KBL Berbasis Baterai berdasarkan jenisnya dikelompokan ke dalam KBL Berbasis Baterai beroda dua dan/atau tiga; dan KBL Berbasis Baterai beroda empat atau lebih. ${ }^{17}$

Salah satu usaha percepatan program KBL Berbasis Baterai untuk transportasi jalan sebagaimana diamanahkan dalam Perpres 55/2019 ialah melalui pemberian insentif oleh Pemerintah Pusat dan Pemerintah Daerah, yang dapat berupa insentif fiskal dan insentif nonfiskal. ${ }^{18}$ Amanah tersebut lah yang kemudian dituangkan dalam Pergub 3/2020 melalui pemberian insentif fiskal berupa pembebasan pajak daerah berupa BBNKB.

Seiring dengan tujuan otonomi daerah yang mendekatkan pelayanan pemerintah dengan rakyatnya, maka fungsi pajak daerah tidak semata-mata untuk mengisi kas daerah (APBD), karena hal tersebut tidak sesuai dengan tujuan otonomi daerah. Dalam definisi pajak sebagai pengisi kas daerah ini, titik berat pajak diletakkan pada fungsi budgeter meskipun terdapat fungsi lain, yaitu fungsi mengatur (regurelend). ${ }^{19}$

14 Adhitya Akbar, “Kualitas Udara DKI Jakarta DI 2019” http://statistik.jakarta.go.id/kualitas-udara-dki-jakarta-di2019/d diunggah 25 September 2019.

15 Khoirun Nisa, “Kualitas Udara di Provinsi DKI Jakarta” http://statistik.jakarta.go.id/kualitas-udara-di-provinsi-dkijakarta/ diunggah 26 Maret 2019.

16 Indonesia, Peraturan Presiden Percepatan Program Kendaraan Bermotor Listrik Berbasis Baterai (Battery Electric Vehicle) Untuk Transportasi Jalan, Perpres 55 Tahun 2019, LN No. 146 Tahun 2019.

17 Indonesia, Peraturan Presiden Percepatan Program Kendaraan Bermotor Listrik Berbasis Baterai (Battery Electric Vehicle) Untuk Transportasi Jalan, Perpres 55 Tahun 2019, LN No. 146 Tahun 2019, Ps. 2 ayat (1).

18 Indonesia, Peraturan Presiden Percepatan Program Kendaraan Bermotor Listrik Berbasis Baterai (Battery Electric Vehicle) Untuk Transportasi Jalan, Perpres 55 Tahun 2019, LN No. 146 Tahun 2019, Ps. 3 huruf b jo. Ps. 17 ayat (1) dan (2).

19 R. Santoso Brotodiharjo, Ilmu Hukum Pajak, (Bandung: Refika Aditama, 1998), hlm. 2. 
Oleh sebab itu, untuk meningkatkan akuntabilitas penyelenggaraan otonomi daerah, Pemerintah Daerah diberi kewenangan menetapkan sendiri peraturan pelaksanaan terkait pemungutan pajak dan retribusi daerahnya ${ }^{20}$. Salah satu jenis pajak daerah yang diatur dalam UU 28/2009 ialah BBNKB yaitu jenis pajak yang kewenangan pemungutannya hanya diberikan kepada pemerintah daerah setingkat provinsi. ${ }^{21}$

Objek pajak BBNKB ialah penyerahan kepemilikan Kendaraan Bermotor, dimana yang termasuk dalam pengertian Kendaraan Bermotor tersebut adalah kendaraan bermotor beroda beserta gandengannya, yang dioperasikan di semua jenis jalan darat; dan kendaraan bermotor yang dioperasikan di air dengan ukuran isi kotor GT 5 (lima Gross Tonnage) sampai dengan GT 7 (tujuh Gross Tonnage).22 Terhadap pengertian Kendaraan Bermotor tersebut dalam UU 29/2009 diberikan pengecualian sebagai berikut: ${ }^{23}$

1) kereta api;

2) Kendaraan Bermotor yang semata-mata digunakan untuk keperluan pertahanan dan keamanan negara;

3) Kendaraan Bermotor yang dimiliki dan/atau dikuasai kedutaan, konsulat, perwakilan negara asing dengan asas timbal balik dan lembaga-lembaga internasional yang memperoleh fasilitas pembebasan pajak dari Pemerintah; dan

4) objek pajak lainnya yang ditetapkan dalam Peraturan Daerah.

Sesuai dengan amanah yang diberikan oleh Undang-Undang Nomor 23 Tahun 2014 tentang Pemerintahan Daerah, selanjutnya disingkat UU 23/2014, pemerintah daerah DKI Jakarta menetapkan peraturan pelaksanaan terkait pemungutan pajak BBNKB melalui Peraturan Daerah DKI Jakarta Nomor 9 Tahun 2010 tentang Bea Balik Nama Kendaraan Bermotor, selanjutnya disingkat Perda DKI 9/2010. Perda DKI 9/2010 yang telah ditetapkan pada tanggal 3 November 2010 menambahkan pengecualian dari pengertian Kendaraan Bermotor yaitu Kendaraan Bermotor yang dimiliki dan/atau dikuasai oleh pabrikan atau importir yang semata-mata disediakan untuk keperluan pameran dan tidak untuk dijual. ${ }^{24}$

Berdasarkan penjelasan tersebut di atas, diketahui bahwa KBL Berbasis Listrik bukan termasuk ke dalam pengecualian atas pengertian Kendaraan Bermotor baik dalam UU 28/2009 maupun Perda DKI 9/2010. Selain itu, dalam Pasal 9 ayat (3) huruf d UU 28/2009 juga memberikan batasan bahwa pengecualian atas pengertian Kendaraan Bermotor lainnya ditetapkan dalam Peraturan Daerah. Oleh karenanya Pergub 3/2020 jika dikaji berdasarkan teori validitas hukum yang salah satunya mempersyaratkan adanya kesesuaian antara peraturan yang lebih rendah atau yang

20 Indonesia, Undang-Undang Pemerintahan Daerah, UU No. 23 Tahun 2014, LN No. 244 Tahun 2014, TLN No. 5587, Ps. 286 ayat (1).

21 Indonesia, Undang-Undang Pajak Daerah dan Retribusi Daerah, UU No. 28 Tahun 2009, LN No. 130 Tahun 2009, TLN No. 5049, Ps. 2 ayat (1).

22 Indonesia, Undang-Undang Pajak Daerah dan Retribusi Daerah, UU No. 28 Tahun 2009, LN No. 130 Tahun 2009, TLN No. 5049, Ps. 9 ayat (1) dan (2).

23 Indonesia, Undang-Undang Pajak Daerah dan Retribusi Daerah, UU No. 28 Tahun 2009, LN No. 130 Tahun 2009, TLN No. 5049, Ps. 9 ayat (3).

24 DKI Jakarta, Peraturan Daerah Provinsi Bea Balik Nama Kendaraan Bermotor, Perda DKI No. 9 Tahun 2010, LDP No. 9 Tahun 2010, TLDP No. 6, Ps. 3 ayat (3). 
bersifat khusus dengan peraturan yang tingkatannya lebih tinggi atau yang bersifat umum, dapat dikatakan sebagai suatu peraturan yang bertentangan dengan UU 28/2009 sebagai undang-undang yang memiliki tingkatan lebih tinggi dan bersifat umum.

Menelisik tingkatan antara Peraturan Daerah dengan Peraturan Gubernur, menurut Pasal 8 ayat (2) Undang-Undang Nomor 12 Tahun 2011 tentang Pembentukan Peraturan Perundang-undangan, selanjutnya disingkat UU 12/2011, peraturan yang ditetapkan oleh Gubernur diakui keberadaannya dan mempunyai kekuatan hukum mengikat sepanjang diperintahkan oleh peraturan perundang-undangan yang lebih tinggi (dalam hal ini juga termasuk Peraturan Daerah Provinsi) ${ }^{25}$ atau dibentuk berdasarkan kewenangan. ${ }^{26}$ Pada bagian menimbang dalam Pergub 3/2020 dijelaskan bahwa pembentukan peraturan gubernur ini ialah sebagai tindak lanjut dari ketentuan Pasal 17 ayat (1) dan (2) Perpres 55/2019 yang menurut UU 12/2011 memiliki tingkatan yang lebih tinggi darinya. Sehingga jika Pergub 3/2020 dikaji berdasarkan teori validitas hukum dari sudut pandang Perpres 55/2019 dapat dianggap telah memenuhi persyaratan adanya harmonisasi karena telah dilaksanakan sesuai dengan hierarki peraturan perundang-undangan yang berlaku.

\section{Kewenangan Pemerintah Daerah DKI Jakarta Berdasarkan Undang-Undang Pemerintahan Daerah Terkait Pemberian Insentif Tidak Kena Pajak BBNKB Terhadap KBL Berbasis Baterai}

Menurut pengertian umum atau bahasa, kata "kekuasaan" berasal dari kata "kuasa" artinya kemampuan atau kesanggupan (untuk berbuat sesuatu); kekuatan. ${ }^{27}$ Sedangkan wewenang adalah (1) hak dan kekuasaan untuk bertindak atau melakukan sesuatu; (2) kekuasaan membuat keputusan, memerintah dan melimpahkan tanggung jawab kepada orang lain. ${ }^{28}$ Soerjono Soekanto mengemukakan pengertian "kekuasaan" sebagai kemampuan untuk mempengaruhi pihak lain menurut kehendak yang ada pemegang kekuasaan. Dijelaskan lebih lanjut bahwa adanya kekuasaan tergantung dari hubungan antara penguasa dan yang dikuasai, atau dengan kata lain antara pihak yang memiliki kemampuan melancarkan pengaruh dan pihak lain menerima pengaruh itu dengan rela atau karena terpaksa. Beda antara "kekuasaan" dan "wewenang" (authority) adalah bahwa setiap kemampuan untuk mempengaruhi pihak lain dapat dinamakan kekuasaan, sedang "wewenang" adalah kekuasaan yang ada pada seseorang atau kelompok orang yang mempunyai dukungan atau mendapat pengakuan dari masyarakat. ${ }^{29}$

Undang-Undang Dasar Negara Republik Indonesia Tahun 1945 sebagai dasar hukum negara Republik Indonesia telah menetapkan Indonesia sebagai negara kesatuan dengan sistem desentralistik. Desentralisasi diberikan pengertian sebagai penyerahan wewenang (transfer of authority), termasuk didalamnya policy making

\footnotetext{
25 Tri Jata Ayu Pramesti, "Perbedaan Pergub dengan Perda" https://www.hukumonline.com/klinik/detail/ulasan/lt510e536c2e2e5/perbedaan-pergub-dengan-perda/\# ftn8, diunggah 18 Januari 2017.

26 Indonesia, Undang-Undang Pembentukan Peraturan Perundang-undangan, UU No. 12 Tahun 2011, LN No. 82 Tahun 2011, TLN No. 5234, Ps. 8 ayat (2).

27 Anton M. Moeliono, et al., Kamus Umum Bahasa Indonesia, (Jakarta: Balai Pustaka, 1995), hlm. 533.

28 Ibid., hlm. 1128.

29 Soerjono Soekanto, Pokok-Pokok Sosiologi Hukum, (Jakarta: Rajawali Pers, 1988), hlm. 79-80.
} 
dan policy executing, yakni berwenang membuat kebijakan sendiri dan sekaligus melaksanakannya. ${ }^{30} \mathrm{Hal}$ tersebut tercermin dalam pemberian wewenang kepada Pemerintah Daerah untuk mengatur dan mengurus sendiri Urusan Pemerintahan menurut asas otonomi dan tugas pembantuan, serta diberikan otonomi yang seluasluasnya, kecuali Urusan Pemerintahan yang oleh undang-undang ditentukan sebagai urusan Pemerintah Pusat. ${ }^{31}$

Urusan Pemerintahan terdiri atas urusan pemerintahan absolut yang sepenuhnya menjadi kewenangan Pemerintah Pusat; urusan pemerintahan konkuren yang kewenangannya dibagi antara Pemerintah Pusat dan Daerah yang juga menjadi dasar pelaksanaan otonomi daerah; dan urusan pemerintahan umum yang menjadi kewenangan Presiden sebagai kepala pemerintahan. ${ }^{32}$ Pembagian urusan pemerintahan konkuren antara Pemerintah Pusat dan Daerah didasarkan pada prinsip akuntabilitas, efisiensi, dan eksternalitas, serta kepentingan strategis nasional. ${ }^{33}$ Urusan pemerintahan konkuren yang menjadi kewenangan daerah terdiri atas Urusan Pemerintahan Wajib dan Urusan Pemerintahan Pilihan meliputi hal-hal sebagai berikut:

30 Kardin M. Simanjuntak, "Implementasi Kebijakan Desentralisasi Pemerintahan di Indonesia”, Jurnal Bina Praja, Vol. 7, No. 2, Juni 2015, hlm. 114.

31 Indonesia, Undang-Undang Dasar Negara Republik Indonesia Tahun 1945, Ps. 18 ayat (2) dan (5).

32 Indonesia, Undang-Undang Pemerintahan Daerah, UU No. 23 Tahun 2014, LN No. 244 Tahun 2014, TLN No. 5587, Ps. 9.

33 Indonesia, Undang-Undang Pemerintahan Daerah, UU No. 23 Tahun 2014, LN No. 244 Tahun 2014, TLN No. 5587, Ps. 13 ayat (1). 


\begin{tabular}{|c|c|c|}
\hline \multicolumn{2}{|c|}{ Berkaitan dengan Pelayanan Dasar } & $\begin{array}{l}\text { Tidak Berkaitan } \\
\text { Pelayanan Dasar }\end{array}$ \\
\hline 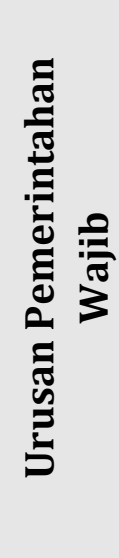 & $\begin{array}{l}\text { a. pendidikan; } \\
\text { b. kesehatan; } \\
\text { c. pekerjaan umum dan } \\
\text { penataan ruang; } \\
\text { d. perumahan rakyat dan } \\
\text { kawasan permukiman; } \\
\text { e. ketenteraman, ketertiban } \\
\text { umum, dan pelindungan } \\
\text { masyarakat; dan } \\
\text { f. sosial. }\end{array}$ & $\begin{array}{l}\text { a. tenaga kerja; } \\
\text { b. pemberdayaan perempuan dan } \\
\text { pelindungan anak; } \\
\text { c. pangan; } \\
\text { d. pertanahan; } \\
\text { e. lingkungan hidup; } \\
\text { f. administrasi kependudukan dan } \\
\text { gencatatan sipil; } \\
\text { g. pemberdayaan masyarakat dan } \\
\text { Desa; }\end{array}$ \\
\hline 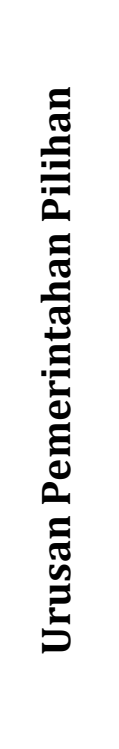 & $\begin{array}{l}\text { a. kelautan dan perikanan; } \\
\text { b. pariwisata; } \\
\text { c. pertanian; } \\
\text { d. kehutanan; } \\
\text { e. energi dan sumber daya } \\
\text { mineral; } \\
\text { f. perdagangan; } \\
\text { g. perindustrian; dan } \\
\text { h. transmigrasi. }\end{array}$ & $\begin{array}{l}\text { h. pengendalian penduduk dan } \\
\text { keluarga berencana; } \\
\text { i. perhubungan; } \\
\text { j. komunikasi dan informatika; } \\
\text { k. koperasi, usaha kecil, dan } \\
\text { menengah; } \\
\text { l. penanaman modal; } \\
\text { m. kepemudaan dan olahraga; } \\
\text { n. statistik; } \\
\text { o. persandian; } \\
\text { p. kebudayaan; } \\
\text { q. perpustakaan; dan } \\
\text { r. kearsipan. }\end{array}$ \\
\hline
\end{tabular}

Sumber: Undang-Undang Nomor 23 Tahun 2014 tentang Pemerintahan Daerah Ps. 12

Pada era otonomi daerah, dengan diberlakukannya Undang-Undang Nomor 32 Tahun 2004 tentang Pemerintahan Daerah, selanjutnya disingkat UU 32/2004, dan UndangUndang Nomor 33 Tahun 2004 tentang Perimbangan Keuanan Pusat dan Daerah, selanjutnya disingkat UU 33/2004, telah menciptakan paradigma yang berdampak pada pelimpahan kewenangan dalam perumusan dan pelaksanaan kebijakan di tingkat daerah. ${ }^{34}$ Menurut Nurmayani bahwa konsekuensi logis dari pemberian otonomi kepada daerah adalah juga diikuti dengan memformulasikan model perimbangan keuangan antara pusat dan daerah secara berimbang agar daerah

34 Sri Hartini dan Setiajeng Kadarsih, "Analisis Terhadap Implementasi Kebijakan Pengelolaan Jalan di Kabupaten Banyumas", Jurnal Dinamika Hukum, Vol. 12, No. 2, Mei 2012, hlm. 285. 
mampu membiayai pelaksanaan urusan pemerintahan yang menjadi kewenangannya. ${ }^{35}$

UU 23/2014 telah mengamanahkan Pemerintah Daerah untuk menjalankan Urusan Pemerintahan Wajib yang wajib diselenggarakan oleh semua daerah dan Urusan Pemerintahan Pilihan yang wajib diselenggarakan oleh daerah sesuai dengan potensi yang dimiliki daerah. ${ }^{36}$ Selanjutnya Urusan Pemerintahan Wajib dalam UU 23/2014 dibagi menjadi Urusan Pemerintahan Wajib yang berkaitan dengan Pelayanan Dasar atau pelayanan publik untuk memenuhi kebutuhan dasar warga negara ${ }^{37}$; dan Urusan Pemerintahan Wajib yang tidak berkaitan dengan Pelayanan Dasar. ${ }^{38}$

DKI Jakarta sebagai sebagai Daerah Otonom yang berkedudukan sebagai Ibukota Negara Kesatuan Republik Indonesia, selanjutnya disingkat NKRI, diberikan kekhususan tugas, hak, kewajiban, dan tanggung jawab dalam penyelenggaraan pemerintahan daerah. Kewenangan Pemerintah Provinsi DKI Jakarta sebagai Ibukota NKRI meliputi penetapan dan pelaksanaan kebijakan dalam bidang sebagaimana diamanahkan oleh Undang-Undang Nomor 93 Tahun 2007 tentang Pemerintahan Provinsi Daerah Khusus Ibukota Jakarta Sebagai Ibukota Negara Kesatuan Republik Indonesia, selanjutnya disingkat UU 93/2007, sebagai berikut: 39

1) tata ruang, sumber daya alam, dan lingkungan hidup;

2) pengendalian penduduk dan permukiman;

3) transportasi;

4) industri dan perdagangan; dan

5) pariwisata.

Salah satu bentuk bentuk Urusan Pemerintah sebagaimana diamanahkan dalam UU 23/2014 dan UU 93/2007 ialah mengenai lingkungan hidup. Lebih lanjut dalam Lampiran UU 23/2014 dijelaskan mengenai sub bidang pengendalian pencemaran dan/atau kerusakan lingkungan hidup dimana pemerintah provinsi diberi tanggung jawab terkait pencegahan, penanggulangan dan pemulihan pencemaran dan/atau kerusakan lingkungan hidup lintas daerah kabupaten/kota dalam 1 (satu) daerah provinsi. ${ }^{40}$ Hal tersebut tentu dapat dikatakan sejalan dengan upaya Pemerintah Pusat dalam mengupayakan kualitas udara bersih dan ramah lingkungan melalui percepatan program kendaraan bermotor listrik berbasis baterai untuk transportasi

35 Nurmayani, et al., "Implikasi Hukum Peralihan Kewenangan Pemungutan PBB P2 dari Pemerintah Pusat kepada Pemerintah Kabupaten/Kota (Studi di Kota Bandar Lampung), Praevia Jurnal Ilmu Hukum, Vol. 6, No. 2, Juli 2012, hlm. 149.

36 Indonesia, Undang-Undang Pemerintahan Daerah, UU No. 23 Tahun 2014, LN No. 244 Tahun 2014, TLN No. 5587, Ps. 1 angka 14 dan 15.

37 Indonesia, Undang-Undang Pemerintahan Daerah, UU No. 23 Tahun 2014, LN No. 244 Tahun 2014, TLN No. 5587, Ps. 1 angka 16.

38 Indonesia, Undang-Undang Pemerintahan Daerah, UU No. 23 Tahun 2014, LN No. 244 Tahun 2014, TLN No. 5587, Ps. 11 ayat (2).

39 Indonesia, Undang-Undang Pemerintahan Provinsi Daerah Khusus Ibukota Jakarta Sebagai Ibukota Negara Kesatuan Republik Indonesia, UU No. 29 Tahun 2007, LN No. 93 Tahun 2007, TLN No. 4744, Ps. 26 ayat (4).

40 Indonesia, Undang-Undang Pemerintahan Daerah, UU No. 23 Tahun 2014, LN No. 244 Tahun 2014, TLN No. 5587, Lampiran hlm. 44. 
jalan karena mobil listrik tidak menghasilkan emisi kendaraan bermotor sehingga tidak menyebabkan kerusakan lingkungan, dalam hal ini ialah polusi udara ${ }^{41}$.

Sehingga jika menelisik dari segi fungsi utama pemungutan pajak yaitu sebagai penerimaan utama kas daerah, pemberian insentif tidak kena pajak BBNKB terhadap KBL Berbasis Baterai dapat dikatakan kurang sesuai karena dapat mengurangi pemasukan kas daerah dalam rangka pembangunan daerah, khususnya provinsi DKI Jakarta. Namun kebijakan tersebut juga harus dipandang dari sisi lainnya yaitu terkait tanggung jawab negara/pemerintah dalam penyediaan semua kebutuhan rakyatnya dalam rangka mencapai tujuan sebagai negara kesejahteraan sebagaimana dikemukakan oleh Otto von Bismarck dalam teori welfare state. Menurut teori welfare state, kebijakan yang dikeluarkan oleh Gubernur DKI Jakarta tersebut merupakan suatu kewajiban karena penyediaan kebutuhan rakyat tidak hanya terbatas pada pembangunan daerah melalui pengembangan infrastruktur saja, melainkan juga terkait dengan peningkatan kualitas hidup masyarakatnya, salah satunya dari segi kesehatan dengan memastikan masyarakatnya dapat hidup di lingkungan yang memiliki kualitas udara yang baik.

\section{PENUTUP}

\section{KESIMPULAN}

Berdasarkan hasil penelitian dan pembahasan yang telah diuraikan, dapat disimpulkan hal-hal sebagai berikut:

1) KBL Berbasis Listrik walaupun secara umum termasuk ke dalam kategori Kendaraan Bermotor sebagaimana diterjemahkan dalam UU 28/2009 dan Perda DKI 9/2010, Gubernur DKI Jakarta, melalui Pergub 3/2020 memberikan insentif tidak kena pajak BBNKB terhadap KBL Berbasis Baterai. Hal ini jika dikaji berdasarkan teori validitas hukum yang salah satunya mempersyaratkan adanya kesesuaian antara peraturan yang lebih rendah atau yang bersifat khusus dengan peraturan yang tingkatannya lebih tinggi atau yang bersifat umum, dapat dikatakan bahwa Pergub 3/2020 merupakan suatu peraturan yang bertentangan dengan UU 28/2009 sebagai undang-undang yang memiliki tingkatan lebih tinggi dan bersifat umum. Namun penerbitan Pergub 3/2020 jika dikaji berdasarkan teori validitas hukum dari sudut pandang Perpres 55/2019 dapat dianggap telah memenuhi persyaratan adanya harmonisasi karena telah dilaksanakan sesuai dengan hierarki peraturan perundang-undangan yang berlaku, yaitu sebagai tindak lanjut dari ketentuan Pasal 17 ayat (1) dan (2) Perpres 55/2019 yang menurut UU 12/2011 memiliki tingkatan yang lebih tinggi darinya.

2) Pemerintah Daerah diamanahkan oleh UU 23/2014 dan UU 93/2007, sebagai konsekuensi pemberian otonomi daerah, untuk mengurus urusan rumah tangganya sendiri yaitu salah satunya terkait dengan sub bidang pengendalian pencemaran dan/atau kerusakan lingkungan hidup dimana pemerintah provinsi diberi tanggung jawab terkait pencegahan, penanggulangan dan pemulihan pencemaran dan/atau kerusakan lingkungan hidup lintas daerah kabupaten/kota dalam 1 (satu) daerah provinsi. Hal ini jika ditelisik dari segi fungsi utama

41 Xehi Dekirty, "5 Kelebihan Mobil Listrik yang Tidak Dimiliki oleh Mobil BBM" https://www.idntimes.com/automotive/car/xehi-dekirty/kelebihan-mobil-listrik-yang-tidak-dimiliki-oleh-mobilbbm-c1c2/full, diunggah 16 Juli 2019. 
pemungutan pajak yaitu sebagai penerimaan utama kas daerah dapat dikatakan kurang sesuai karena dapat mengurangi pemasukan kas daerah dalam rangka pembangunan daerah, khususnya provinsi DKI Jakarta. Namun jika pemberian insentif tersebut dipandang dari pembebanan tanggung jawab negara/pemerintah dalam penyediaan semua kebutuhan rakyatnya dalam rangka mencapai tujuan sebagai negara kesejahteraan menurut teori welfare state, ia termasuk ke dalam salah satu kewajiban Pemerindah Daerah yaitu melalui peningkatan kualitas hidup masyarakatnya, khususnya dari segi kesehatan dengan memastikan masyarakatnya dapat hidup di lingkungan yang memiliki kualitas udara yang baik.

\section{SARAN}

Berdasarkan kesimpulan yang telah dijelaskan sebelumnya, Penulis dapat memberikan saran sebagai berikut:

1) Dalam membuat peraturan perundang-undangan, para pembuat undang-undang sudah seharusnya melaksanakannya sesuai dengan hierarki peraturan perundang-undangan yang berlaku dalam UU 12/2011 secara konsisten dan berurutan agar mudah dicerna oleh para awam hukum dan tidak menimbulkan multi persepsi.

2) Tugas yang diemban pemerintah untuk memastikan masyarakatnya dapat hidup di lingkungan yang memiliki kualitas udara yang baik hanya dapat diperoleh jika masyarakatnya sendiri pun ikut berpartisipasi mendukung program-program pemerintah terkait hal tersebut, dalam hal ini ialah percepatan program KBL Berbasis Baterai untuk transportasi jalan sehingga potensi kehilangan pemasukan kas daerah yang telah diperhitungkan oleh Pemerintah Daerah DKI Jakarta tersebut tidak menjadi hal yang sia-sia.

\section{DAFTAR PUSTAKA}

\section{Peraturan Perundang-undangan}

DKI Jakarta. (2010). Peraturan Daerah Provinsi Nomor 9 Tahun 2010 tentang Bea Balik Nama Kendaraan Bermotor. Jakarta: Lembaran Daerah Provinsi Daerah Khusus Ibukota Jakarta Tahun 2010 Nomor 9.

Gubernur Daerah Khusus Ibukota Jakarta. (2019). Peraturan Gubernur Nomor 3 Tahun 2020 tentang Insentif Pajak Bea Balik Nama Kendaraan Bermotor Atas Kendaraan Bermotor Listrik Berbasis Baterai (Battery Electric Vehicle) Untuk Transportasi Jalan. Jakarta: Berita Daerah Provinsi Daerah Khusus Ibukota Jakarta Tahun 2019 Nomor 61056.

Republik Indonesia. (1945). Undang-Undang Dasar Negara Republik Indonesia Tahun 1945. Jakarta.

Republik Indonesia. (1999). Peraturan Pemerintah Nomor 41 Tahun 1999 tentang Pengendalian Pencemaran Udara. Jakarta: Lembaran Negara Republik Indonesia Tahun 1999 Nomor 86.

Republik Indonesia. (2003). Undang-Undang Nomor 17 Tahun 2003 tentang Keuangan Negara. Jakarta: Lembaran Negara Republik Indonesia Tahun 2003 Nomor 47. 
Republik Indonesia. (2007). Undang-Undang Nomor 29 Tahun 2007 tentang Pemerintahan Provinsi Daerah Khusus Ibukota Jakarta Sebagai Ibukota Negara Kesatuan Republik Indonesia. Jakarta: Lembaran Negara Republik Indonesia Tahun 2007 Nomor 93.

Republik Indonesia. (2009). Undang-Undang Nomor 28 Tahun 2009 tentang Pajak Daerah dan Retribusi Daerah. Jakarta: Lembaran Negara Republik Indonesia Tahun 2009 Nomor 130.

Republik Indonesia. (2011). Undang-Undang Nomor 12 Tahun 2011 tentang Pembentukan Peraturan Perundang-undangan. Jakarta: Lembaran Negara Republik Indonesia Tahun 2011 Nomor 82.

Republik Indonesia. (2014). Undang-Undang Nomor 23 Tahun 2014 tentang Pemerintahan Daerah. Jakarta: Lembaran Negara Republik Indonesia Tahun 2014 Nomor 244.

Republik Indonesia. (2019). Peraturan Presiden Nomor 55 Tahun 2019 tentang Percepatan Program Kendaraan Bermotor Listrik Berbasis Baterai (Battery Electric Vehicle) Untuk Transportasi Jalan. Jakarta: Lembaran Negara Republik Indonesia Tahun 2019 Nomor 146.

\section{Buku}

Abuyamin, O. (2015). Perpajakan. Bandung: Mega Rancage Press.

Anton M. Moeliono, e. a. (1995). Kamus Umum Bahasa Indonesia. Jakarta: Balai Pustaka.

Brotodiharjo, R. S. (1998). Ilmu Hukum Pajak. Bandung: Refika Aditama.

Dimyati, K. (2004). Teorisasi Hukum: Studi tentang Perkembangan Pemikiran Hukum di Indonesia 1945-1990. Surakarta: Universitas Muhammadiyah Surakarta Press.

Fuady, M. (2013). Teori-Teori Besar Dalam Hukum (Grand Theory). Jakarta: Kencana.

Ismail, T. (2018). Potret Pajak Daerah di Indonesia. Jakarta: Prenamedia Group.

Lubis, S. (2002). Hukum Tata Negara. Bandung: Mandar Madju.

Soekanto, S. (1988). Pokok-Pokok Sosiologi Hukum. Jakarta: Rajawali Pers.

Soemitro, R. (1991). Asas dan Dasar Perpajakan. Bandung: Eresco.

Suharto, E. (2009). Membangun Masyarakat Memberdayakan Rakyat: Kajian Strategis Pembangunan Kesejahteraan Sosial Dan Pekerjaan Sosial. Bandung: PT Refika Aditama.

Warassih, E. (2009). Pranata Hukum: Sebuah Telaah Sosiologis. Semarang: PT Suryandaru Utama.

Widjaja, H. (2002). Otonomi Daerah dan Daerah Otonom. Jakarta: RajaGrafindo Persada.

\section{Artikel Jurnal dan Makalah}


Elviandri, K. D. (2019, Juni). Quo Vadis Negara Kesejahteraan: Meneguhkan Ideologi Welfare State Negara Hukum Kesejahteraan Indonesia. Mimbar Hukum, 31(2), 252266.

Keech, W. R. (2012, Februari 27). Market Failure and Government Failure.

Lutfi, A. (2006, Januari). Penyempurnaan Administrasi Pajak Daerah dan Retribusi Daerah: Suatu Upaya dalam Optimalisasi Penerimaan PAD. Jurnal Ilmu Administrasi dan Organisasi: Bisnis \& Birokrasi, XIV(1), 1-10.

Nurmayani, e. a. (2012, Juli). Implikasi Hukum Peralihan Kewenangan Pemungutan PBB P2 dari Pemerintah Pusat kepada Pemerintah Kabupaten/Kota (Studi di Kota Bandar Lampung). Praevia Jurnal Ilmu Hukum, 6(2), 149-160.

Simanjuntak, K. M. (2015, Juni). Implementasi Kebijakan Desentralisasi Pemerintahan di Indonesia. Jurnal Bina Praja, 7(2), 111-130.

Soegiyono. (2015). Pentingnya Harmonisasi Pembentukan Peraturan Perundangundangan. Kajian Kebijakan dan Hukum Kedirgantaraan, 1-21.

Soemitro, R. (1986, Maret 14). Pengantar Singkat Hukum Pajak. Makalah Lokakarya Pendidikan dan Pelatihan Keuangan dan Perpajakan/Pendapatan Daerah.

Sri Hartini, S. K. (2012, Mei). Analisis Terhadap Implementasi Kebijakan Pengelolaan Jalan di Kabupaten Banyumas. Jurnal Dinamika Hukum, 12(2), 284-294.

\section{Internet}

Akbar, A. (2019, September 25). Kualitas Udara DKI Jakarta DI 2019. Diambil kembali dari Portal Statistik Sektoral Provinsi DKI Jakarta: http://statistik.jakarta.go.id/kualitasudara-dki-jakarta-di-2019/

Dekirty, X. (2019, Juli 16). 5 Kelebihan Mobil Listrik yang Tidak Dimiliki oleh Mobil BBM. Diambil kembali dari IDN Times: https://www.idntimes.com/automotive/car/xehidekirty/kelebihan-mobil-listrik-yang-tidak-dimiliki-oleh-mobil-bbm-c1c2/full

Kementerian Keuangan Republik Indonesia. (2020, April 1). APBN 2019. Diambil kembali dari Kementerian Keuangan Republik Indonesia: https://www.kemenkeu.go.id/apbn2019

Nisa, K. (2019, Maret 26). Kualitas Udara di Provinsi DKI Jakarta. Diambil kembali dari Portal Statistik Sektoral Provinsi DKI Jakarta: http://statistik.jakarta.go.id/kualitasudara-di-provinsi-dki-jakarta/

Nugroho, S. S. (2020, Maret 25). Harmonisasi Peraturan Perundang-Undangan. Diambil kembali dari Jaringan Dokumentasi dan Informasi Hukum Kementerian Riset, Teknologi, dan Pendidikan Tinggi Republik Indonesia: http://jdih.ristekdikti.go.id/v0/?q=system/files/dokumentasi/586130112.pdf

Pramesti, T. J. (2017, Januari 18). Perbedaan Pergub dengan Perda. Diambil kembali dari Hukumonline.com: 
Widya Yuridika: Jurnal Hukum, Volume 3 / Nomor 2 / Desember 2020 https://www.hukumonline.com/klinik/detail/ulasan/lt510e536c2e2e5/perbedaan -pergub-dengan-perda/\#_ftn8 
